\title{
Práva osob se zdravotním postižením opouštějících školská zařízení a jejich ochrana v praxi sociálního pracovníka na obci
}

\section{The Rights of People with Disabilities and their Protection in the Practice of a Social Worker in the Municipality}

Mgr. Zuzana Machová1, Krajský úřad Královéhradeckého kraje, Hradec Králové

\section{Abstrakt}

Text hovoří o podpoře osob s omezenými právy opouštějící školská zařízení po dosažení zletilosti a možnosti jejich podpory v rámci vǵkonu veřejného opatrounictví a sociální práce na obci.

\section{Klíčová slova}

sociální práce na obci, ochrana práv osob, školy a školská zařízení

\section{Abstract}

The text speaks of support for persons with limited rights leaving school facilities after reaching the age of majority and the possibility of their support within the exercise of public guardianship and social work in the municipality.

\section{Keywords}

social work in the municipality, protection of the rights of persons, schools and school facilities

\section{Úvod}

Tématem příspěvku je návrh spolupráce sociální práce na obci, opatrovníků a pracovníků škol a školských zařízení nad klienty, kteří vhledem ke svému zdravotnímu stavu potřebují podporu v právních věcech ve všech formách, které umožňuje občanský zákoník. Cúlem př́ispěvku je domluvit se na kritériích, podle kterých by se aktéři domlouvali na praxi, kdy je dobré klienta podpořit mírnějšśmi opatřeními formulovanými občanským zákoníkem. Pokud je pro klienta užitečné omezit ho na právech nejstriktnější formou - omezení práv a jmenováním opatrovníka, je dobré domluvit i rozsah jeho omezení.

\section{Současný stav poznání}

Sociální práce na obci

Druhým aktérem, který může být nápomocný osobě s potřebou podpory, je sociální pracovník na obci. Sociální práce na obci je na obcích III. a II. typu realizována od roku 2012. Výše zmíněné obce tvoří sít pomoci na území celé republiky. V královéhradeckém kraji funguje 15 obcí III. typu a 20 obcí II. typu. ${ }^{2}$ Sociální pracovník na obci spolupracuje se všemi cílovými skupinami -

Sociální pracovník na obci může být první kontaktní osobou pro rodinu s dítětem se zdravotním postižením. V tomto případě sociální pracovník plní roli toho, kdo zná poskytovatele sociálních a zdravotních služeb, sítě škol a školských zařízení. Zároveň umí promluvit s rodinou, která řeší péči o zdravotně 
postiženého dítěte, a může prožívat krizi v souvislosti se zdravotním stavem dítěte a jeho budoucností. Sociální pracovník v rámci poradenství sdělí informace o možnosti dávkového systému, kompenzačních pomůcek a další.

Na obcích III. typu pracuje sociální pracovník se specializací kurátora (kurátor pro dospělé, sociální kurátor) ${ }^{3}$, který v případě dětí opouštějících školská zařízení spolupracuje s kurátorem pro děti a mládež ${ }^{4}$

Výkon sociální práce na obci je přenesenou působností. ${ }^{5}$ To v praxi znamená, že krajské úřady poskytují metodickou pomoc obcím. Metodická pomoc má různorodou podobu. Pořádá porady, vzdělávání, metodické dohlídky, případové konference, řeší individuální případy, spolupracuje s obcemi, poskytovateli sociálních, zdravotních a dalších služeb a další.

Krajský úřad Královéhradeckého kraje realizuje metodickou pomoc také od roku 2016 prostřednictvím individuálních projektů Rozvoj dostupnosti a kvality sociálních služeb v Královéhradeckém kraji $\mathrm{V}^{6}, \mathrm{VI}^{7}, \mathrm{VII}^{8}$.

K metodické činnosti krajského úřadu patří školení a účast na poradách u spolupracujících organizací.

Krajský úřad realizuje také kontrolní činnost.

\section{Veřejné opatrovnictví}

Veřejní opatrovníci obcí vykonávají v České republice opatrovnictví u 13645 opatrovaných osob9 . V Královéhradeckém kraji je k 31. 3. 2021 opatrovnictví vykonáváno u 802 opatrovaných osob.

Tab. 1 Počty opatrovaných osob v letech 2016-20210

\begin{tabular}{|r|r|r|r|r|r|r|}
\hline Počet opatrovanců v roce: & 2016 & 2017 & 2018 & 2019 & 2020 & 2021 \\
\hline Celkem v ČR & 10799 & 11485 & 12196 & 12822 & 13452 & 13645 \\
\hline Královéhradecký kraj & 679 & 706 & 736 & 764 & 789 & 802 \\
\hline
\end{tabular}

Opatrovnictví ve smyslu omezení práv u dospělé osoby je legislativně upraveno zákonem č. 89/2012 Sb., v posledním znění, občanský zákoník. Takto definované opatrovnictví můžou vykonávat jak fyzické osoby - rodinní příslušníci, přátelé, okolí opatrované osoby. Další možností je výkon opatrovnictví obcí, pokud opatrovaná osoba nikoho ve svém okolí nemá, kdo by hájil její práva. V tom případě hovoříme o výkonu veřejného opatrovnictví. Práva může dospělé osobě omezit pouze soud. V tomto článku se budeme zabývat pouze opatrovnictvím veřejným.

Východiskem pro změnu nazírání na opatrovnictví a omezení práv v České republice byla ratifikace Úmluvy o právech osob se zdravotním postižením¹․ Ratifikace Úmluvy o právech osob se zdravotním postižením byla impulzem ke změně přístupu právě k osobám, které potřebují ochranu v oblasti hájení práv. Východiskem právní úpravy do roku 2014 bylo náhradní rozhodování. To znamenalo v praxi, že člověk mohl být zbaven práv úplně, v tom případě za něj v celém rozsahu rozhodoval opatrovník.

Nová právní úprava účinná po roce 2014 nahlíží na práva a rozhodování zpơsobem opačným - rozhodování by mělo být podporující a ve spolupráci opatrované osoby a opatrovníka. Nová právní úprava zavádí mírnější formy omezení - instituty:

- Zvláštní př́ijemce důchodu ${ }^{12}$

- Nápomoc při rozhodování13

3 § 92 b zákona č. 108/2006 sb., v posledním znění, o sociálních službách.

4 359/1999 Sb. o sociálně-právní ochraně dětí https://www.aspi.cz/products/lawText/1/48272/1/2?vtextu=z\%C3\%A1kon\%20 soci\%C3\%A1ln\%C4\%9B\%20pr\%C3\%A1vn\%C3\%AD\%20ochrana\%20d\%C4\%9Bt\%C3\%AD\#lema0

5 § 149 b zákona č. 128/2000 sb., v posledním znění, o obcích

6 https://socialnisluzby.kr-kralovehradecky.cz/cz/poskytovatele/projekty/rozvoj-5/rozvoj-dostupnosti-a-kvality-socialnich-sluzeb-v-kralovehradeckem-kraji-v-87735/

7 https://socialnisluzby.kr-kralovehradecky.cz/cz/poskytovatele/projekty/rozvoj-6/rozvoj-dostupnosti-a-kvality-socialnich-sluzeb-v-kralovehradeckem-kraji-vi-302138/

8 https://socialnisluzby.kr-kralovehradecky.cz/cz/poskytovatele/projekty/rozvoj-7/rozvoj-dostupnosti-a-kvality-socialnich-sluzeb-v-kralovehradeckem-kraji-vii--321706/

9 K 31. 3. 2021, MV ČR Veřejné opatrovnictví - Ministerstvo vnitra České republiky (mvcr.cz)

10 K 31. 3. 2021, MV ČR Veřejné opatrovnictví - Ministerstvo vnitra České republiky (mvcr.cz)

11 Zákon č. 10/2020 Sb., v posledním znění, Úmluva OSN o právech osob se zdravotním postižením

12 §118 zákona č. 582/1991 sb., v posledním znění, o organizaci a provádění sociálního zabezpečení - Zvláštní příjemce důchodu 13 § 45-48 zákona č. 89/2012 sb., v posledním znění, občanský zákoník. 
- Předběžné prohlášení14

- Zastoupení členem domácnosti ${ }^{15}$

- Opatrovnictví bez omezení svéprávnosti16

K novinkám v podporovaném rozhodování můžeme počítat i opatrovnickou radu zvolenou z okruhu blízkých osob z okolí opatrované osoby. ${ }^{17}$

Osoba, které může soud omezit práva, je pouze člověk s duševním onemocněním nebo mentálním postižením. Soud prověřuje oblasti, ve kterých potřebuje osoba podporu. Pravidlem je, že osobě nejsou omezena práva preventivně, a osobě, které se práva omezují, musí hrozit skutečná újma.

Nejčastější oblasti omezení formulovaná v rozsudcích jsou:

- Správa finančních prostředků - formulace omezení bud' na jednotlivý úkon nebo na období - týden, měsíc

- Smlouvy a smluvní vztahy - pracovně právní, smlouvy s odloženým plněním v budoucnosti

- Pořízení pro případ smrti - pořizování závětí

- Volební právo aktivní i pasívní

- Rodičovská odpovědnost

- Uzavírání manželství a registrovaného partnerství

- Zdravotní úkony

V některých případech soudy formulují v rozsudcích omezení na všechny právní úkony kromě běžných záležitostí každodenního života. ${ }^{18}$ Takto formulované omezení je v žité praxi opatrovníka použitelný pouze z části.

Výkon veřejného opatrovnictví je také přenesenou působností. ${ }^{19}$ Metodická a kontrolní činnost probíhá v obdobném rozsahu jako metodická činnost pro sociální pracovníky obcí.

Krajský úřad Královéhradeckého kraje pro potřeby metodiky pro obce jako veřejné opatrovníky vytvořil metodickou pomůcku - Metodiku výkonu veřejného opatrovnictví. ${ }^{20}$

Pracovníci škol, školských zařízení, speciálně pedagogických center se v indikovaných případech obracejí metodiky krajského úřadu při řešení životní situace rodiny s dítětem, u kterého chtějí pomoci rodině bud' po ukončení studia nebo kolem nabití zletilosti chtějí využít poradenství. Tématem poradenství je nalezení vhodné sociální služby pro mladého člověka po skončení studia, at' už pobytové nebo ambulantní. Dalším tématem je hledání vhodného podpůrného opatření, případně omezení práv. Rodiče pečující o dítě se speciálními potřebami se potřebují zorientovat v informacích, které dostali nap̌r. od lékařơ, sociálních pracovníků, dalších rodičů v podobné situaci apod.

Modelová situace

Rodina s dítětem se speciálními potřebami, které vycházejí ze zdravotního stavu, se potřebuje zorientovat ve své situaci a potřebuje naplánovat budoucnost. Mladý člověk, roč. narození 2004, navštěvuje praktickou školu. Ve škole využívá osobní asistenci, je klientem speciálního pedagogického centra. S pracovníky speciálně pedagogického centra diskutuje mladý člověk a jeho rodina o budoucnosti. Jedna část diskuse řeší možnost využití sociální služby.

Do úvahy připadají služby dle míry podpory, které mladý člověk potřebuje. Jedná se o služby pobytové - chráněné bydlení, domov pro osoby se zdravotním postižením. Je možné uvažovat i o služby terénní nebo ambulantní - pečovatelská služba, podpora samostatného bydlení, sociálně terapeutická dílna, osobní asistence. ${ }^{21} \mathrm{~S}$ výběrem a podáním žádostí do vybrané služby může kromě sociálního pracovníka speciálně pedagogického centra pomoci i sociální pracovník na obci.

Další oblastí, kterou rodina s pracovníky poradenského pracoviště diskutuje, je ochrana práv mladého člověka. Právní úprava nabízí instituty, které je možno využít. Zde je prostor a role metodiky krajského

14 § 38-44 zákona č. 89/2012 sb., v posledním znění, občanský zákoník

15 § 49-54 zákona č. 89/2012 sb., v posledním znění, občanský zákoník.

16 § 469 zákona č. 89/2012 sb., v posledním znění, občanský zákoník.

17 § 472 a následující zákona č 89/2012 sb., v posledním znění, občanský zákoník.

18 Metodická činnost, Krajský úřad Královéhradeckého kraje.

19 § 149 b zákona č. 128/2000 sb., v posledním znění, o obcích.

20 Metodika výkonu veřejného opatrovnictví, 2. přepracované vydání.

https://www.kr-kralovehradecky.cz/cz/krajsky-urad/socialni-oblast/verejne-opatrovnictvi/metodika-vykonu-verejneho-opatrovnictvi-2--prepracovane-vydani-320950/

21 http://iregistr.mpsv.cz/socreg/vitejte.fw.do;jsessionid=0355922AF692BE928E686740A8996DF7.node1?SUBSESSION_ ID=1638256765970_1 
úřadu, sociálních pracovníků obcí, veřejných opatrovníků obce, vyšších soudních úředníků, soudců a dalších, na které se rodina obrátí. Rozhodnout o podpoře v právní oblasti, nebo přímo o omezení práv, je složitý proces, který ovlivní život člověka na dlouhou dobu, v některých případech do konce života.

Pokud je situace člověka, který potřebuje právní podporu, standardní a očekávatelná, je poradenství a metodická pomoc také standardizovaná. V případě, že je situace nestandardní, komplikovaná nejen zdravotním stavem, ale i situací rodiny, vztahově, z důvodů finančních a majetkových, např. má osoba rozsáhlý majetek apod., je na místě zvolit adekvátní metodu spolupráce, např. případovou konferenciei ${ }^{22}$.

Cílem je najít pro člověka takovou formu podpory, která bude funkční, nastavená dlouhodobě, v intencích, které mu budou nápomocny. V žádném případě není účelem nastavit podporu tak, aby člověka omezovala, znesnadňovala mu život v komunitě, nemohla k rozvoji a udržení kompetencí.

Obr. 1 Schéma aktérů pomáhajících osobě s potřebou podpory

\section{Závěr}

Příspěvek krátce zrekapituloval legislativní podmínky podpory osob se zdravotním postižením, podmínky a možnosti zapojených aktérů, jejich dosavadní spolupráci. Výše zmínění jmenovaní vybraní aktéři mohou být nápomoci osobě, která potřebuje podporu k životu ve společnosti. Všichni aktéři jsou vybaveni legislativně, mají svou bohatou praxi a zároveň spolupracují na jednotlivých případech. Je pro praxi užitečné spolupráci ladit, rekapitulovat a zavádět nové poznatky.

Rádi bychom naším příspěvkem vyvolali diskusi mezi osobami s omezenými právy, rodinami, přáteli, opatrovníky, soudy, sociálními pracovníky, obhájci práv a dalšími zainteresovanými osobami a organizacemi. Cílem diskuse by mělo být rozšíření podpůrných prostředků do praxe na úkor omezování práv osob.

\section{Literatura}

Kolektiv autorů (2020) Metodika případových konferencí pro sociální pracovníky na obcích. Krajský úřad Královéhradeckého kraje, Projekt Rozvoj dostupnosti a kvality sociálních služeb v Královéhradeckém kraji VI. Reg. č. CZ.03.2.63./0.0/0.0/15_007/0010322

https://socialnisluzby.kr-kralovehradecky.cz/assets/poskytovatele/projekty/rozvoj-6/Metodika-pripadovych-konferenci-pro-socialni-pracovniky-na-obcich.pdf

Kolektiv autorů (2020) Metodika výkonu veřejného opatrovnictví, 2. přepracované vydání. Krajský úřad Královéhradeckého kraje, Projekt Rozvoj dostupnosti a kvality sociálních služeb v Královéhradeckém kraji VI. Reg. č. CZ.03.2.63./0.0/0.0/15_007/0010322

https://www.kr-kralovehradecky.cz/cz/krajsky-urad/socialni-oblast/verejne-opatrovnictvi/metodika-vykonu-verejneho-opatrovnictvi-2--prepracovane-vydani-320950/

10/2010 Sb., Úmluva o právech osob se zdravotním postižením.

https://www.aspi.cz/products/lawText/1/70385/1/2?vtextu=\%C3\%BAmluva\%20pr\%C3\%A1va\%20 osob\%20se\%20zdravotn\%C3\%ADm\%20posti\%C5\%BEen\%C3\%ADm \#lema0

Zákon č. 1/1993 Sb., ústava

https://www.aspi.cz/products/lawText/1/40450/1/2?vtextu=\%C3\%BAstava\#lema0

Zákon č. 89/2012 Sb., občanský zákoník. https://www.aspi.cz/products/lawText/1/74907/1/2

Zákon 108/2006 Sb., o sociálních službách. https://www.aspi.cz/products/lawText/1/62334/1/2

Zákon č. 111/2006 Sb., o pomoci v hmotné nouzi. https://www.aspi.cz/products/lawText/1/62337/1/2

Zákonč.359/1999Sb.,osociálně-právníochranědětíhttps://www.aspi.cz/products/lawText/1/48272/1/2

Zákon č. 582/1991 Sb. o organizaci a provádění sociálního zabezpečení.

https://www.aspi.cz/products/lawText/1/39631/1/2

22 Metodika případových konferencí pro sociální pracovníky na obcích.

https://socialnisluzby.kr-kralovehradecky.cz/assets/poskytovatele/projekty/rozvoj-6/Metodika-pripadovych-konferenci-pro-

-socialni-pracovniky-na-obcich.pdf 


\section{Informace o autorce}

\section{Mgr. Zuzana Machová}

Pracuje jako metodička sociální práce na obcích a veřejného opatrovnictví obcí Královéhradeckého kraje. Metodickou rolí je vést sociální pracovníky a veřejné opatrovníky, kontrolovat jejich činnost, přinášet nové metody práce, pomáhat řešit dilematické situace kolegů z terénu.

Telefon: +420 595817571

Email: zmachova@kr-kralovehradecky.cz

URL: http://www.kr-kralovehradecky.cz 